Every reader his book - every book its reader?

Notions on audience development for literature in Danish public libraries

Kann-Christensen, Nanna; Balling, Gitte

Published in:

Journal of Librarianship and Information Science

DOI:

$10.1177 / 0961000614532486$

Publication date:

2014

Document version

Early version, also known as pre-print

Citation for published version (APA):

Kann-Christensen, N., \& Balling, G. (2014). Every reader his book - every book its reader? Notions on audience development for literature in Danish public libraries. Journal of Librarianship and Information Science, 1-12. https://doi.org/10.1177/0961000614532486 


\title{
Every reader his book - every book its reader? Notions on readers' advisory and audience development in Danish public libraries
}

Journal of Librarianship and Information Science

C) The Author(s) 2014

Reprints and permissions:

sagepub.co.uk/journalsPermissions.nav DOI: 10.1 177/09610006/4532486 lis.sagepub.com

(S)AGE

\author{
Nanna Kann-Rasmussen' \\ University of Copenhagen, Denmark
}

\section{Gitte Balling}

University of Copenhagen, Denmark

\begin{abstract}
Collections are no longer the main attraction in libraries, and libraries are working to find new paths to tread. One strategy is to focus on reading and literature in new and surprising ways. The aim of this article is to enrich an understanding of activities situated in the span between readers' advisory and audience development. This is achieved through an analysis of opinions and reflections expressed by 13 managers and librarians in all six county libraries in Denmark. The interviews are analysed through the model which merges three concepts: cultural policy, new public management and professional logics. Our findings show that Danish librarians' views on readers' advisory and audience development strike a balance between the experience and empowerment rationales with a prevailing focus on users. A user orientation and focus on user experiences have created a situation wherein the notions of passion, commitment, enthusiasm become central to the work of librarians who champion and manage these activities. However, this strategy has limitations related to the choice of content and intended user groups. Audience development, founded on dedication and experience, tends to cater for users who look and think like librarians.
\end{abstract}

\section{Keywords}

Audience development, cultural policy, literature promotion, public libraries, readers' advisory, users

\section{Introduction}

We can't help but notice that some people think that libraries will be reduced to central storehouses where people can pick up their books. With Google, the Internet and so on, public libraries might be unnecessary in a few years. We do a whole bunch of stuff to try to counteract that. (D1)

This quote from a mid-level manager in a large public library highlights the problem that public libraries all over the western world face today due to a major shift in usage patterns (Bak et al., 2012; Hvenegaard Rasmussen and Jochumsen, 2007; Ross et al., 2006). One strategy that public libraries use to meet the changing demand is shifting their focus from collections to connections (Thorhauge, 2010). 'From collections to connections' is a phrase widely used in Denmark. It signifies the shift whereby public libraries transition from collection centred to user centred and community orientated. The word 'connection' encapsulates communication between librarians and users and between different groups of users, as well as online communication. As a result, libraries have developed many new services over the last 10 years. Some libraries strive to re-envision their physical space to establish the library as a meeting place (Audunson, 2005); others experiment with user-driven initiatives in order to attract young people (Kristiansson, 2007); many libraries have developed new services and activities related to readers' advisory and audience development. The latter - audience development - is the focus of this article. The article discusses views of

\section{Corresponding author:}

Nanna Kann-Rasmussen, University of Copenhagen, Birketinget 6, Copenhagen S, 2300, Denmark.

Email: tdr565@iva.ku.dk 
and opinions on current audience development and readers' advisory conveyed by the employees and managers of Danish public libraries.

Balling and Kann-Christensen (2011) developed the socalled 3Ps model, which can be used to analyse audience development and readers' advisory in public libraries. This model integrates three aspects - Policy, Public Management, and Profession - which interact with each other in the context of readers' advisory, audience development, and literature promotion in public libraries. Cultural policy, or Policy, in conjunction with views and attitudes held by politicians, government officials, managers, and librarians, play an important role in understanding audience development in Danish libraries. Thus the basic premise for the development of the model is that the Policy exerts influence on the concept of audience development and other activities in public libraries, and that the Policy is related to the logics of Public Management and the Profession. Furthermore, the analysis of audience development must take both librarians and library managers into account.

As a result, this article asks the following questions:

- What are the notions of librarians and library managers with regard to the purpose and effects of readers' advisory and audience development?

- How can these notions be interpreted in the context of the 3Ps model?

In this paper we use the terms readers' advisory (henceforth RA) and audience development (henceforth $\mathrm{AD}$ ). $\mathrm{AD}$ is a British term and RA a North American term. Although $\mathrm{AD}$ is a much broader concept, we use $\mathrm{AD}$ and $\mathrm{RA}$ interchangeably in our article to describe activities related to the promotion of reading and literature in public libraries. In Danish, it is difficult to find terms that would distinguish RA from literature promotion or AD. The Danish term 'Litteraturformidling' is inclusive and covers all these activities. ${ }^{2}$ We use both European and North American sources to support our argument; as a result this terminological clarification is necessary in order to reconcile the concepts derived from different sources.

$\mathrm{AD}$ is a term derived from British cultural policy (Kawashima, 2000); it is used to describe 'a strategy that places the arts in the centre of people's lives' (p. 1). Kawashima identifies four different types of AD in Britain:

1. cultural inclusion (outreach);

2. extended marketing (no. 1 and 2 target non-users);

3. taste cultivation (introduction to new art forms and genres); and

4. audience education (no. 3 and 4 target existing audiences).

From the library perspective, this categorization of efforts within $\mathrm{AD}$ comes very close to the aforementioned Danish term Litteraturformidling. The concept of reader development (Ross et al., 2006; Van Riel and Fowler, 1996) is also worth mentioning. Reader development is the British term for $\mathrm{AD}$ in libraries. This concept encompasses RA, promotion and outreach.

In the North American context, the term RA is more commonly used. Whereas AD is presented as a relatively new and recent practice in public libraries, the practice of RA has a longstanding tradition in North American libraries and encompasses a wide array of face-to-face and online services, including direct interactions with readers, book talks, book clubs, the creation of reading guides and websites, and a variety of programmes for individuals and groups (Ross et al., 2006; Shearer and Burgin, 2001).

\section{Article structure}

The article is structured as follows. Firstly we present our data collection and analytical framework. This is followed by a brief overview of the activities related to RA/AD in the six libraries. After that we present our analysis which is structured in three parts. Firstly the benefits for the users are discussed. In this section the what, the how and the why of RA/AD is discussed. Secondly the benefits for the library as an institution are discussed. This section relates to the concept of legitimacy in two ways: RA/AD as an imperative and RA/AD as a means to boost performance. Thirdly we discuss benefits in relation to the librarians. We end the article by presenting a model which allows us to understand some of the notions put forward in the analysis.

\section{Data collection}

Our unit of analysis is the notions of RA/AD as it takes place in six large public libraries. Thus this article does not intend to point to best practices concerning developing and promoting literature, but focuses solely on the spoken accounts given by professionals and managers in the field. For a thorough analysis of the practice itself we refer to Grøn (2010) for a Danish perspective and Ross et al. (2006) for a North American perspective.

The study was carried out through analysis of interviews conducted with central actors in the field. We have conducted in depth interviews with five librarians, two promoters of literature who are not librarians but are educated in literature and six middle managers, all responsible for RA/AD. The interviews were carried out during the fall of 2009 and the winter of $2011^{3}$ and took place in the six Danish county libraries (henceforth referred to as $\mathrm{A}, \mathrm{B}, \mathrm{C}, \mathrm{D}, \mathrm{E}$, and $\mathrm{F}$ ) where 1 refers to managers, 2 refers to librarians and 3 to other academic staff. County libraries are large public libraries which act as county libraries when it comes to 'tasks aimed at a regional co-ordination within a defined geographical 


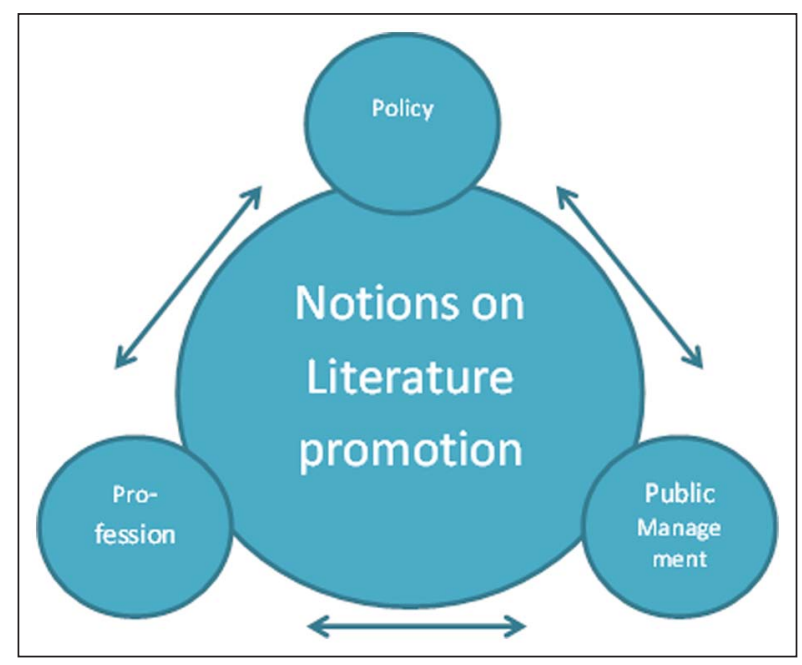

Figure I. 3P's in literature promotion.

Balling and Kann-Christensen, 20I I: 106.

area and at strengthening professional skills in the libraries' (Act Regarding Library Services, 2000). County libraries have been selected due to the fact that large libraries have the capacity and the resources to focus more intensively on RA/AD to the point where several of them have created positions almost solely concerned with these activities. By selecting the six county libraries we cover the whole Danish library field. In each of the six libraries we interviewed a manager and one or two librarians/promoters of literature. It was the managers who decided which members of their staff we should interview. This was done in order to get a breadth in the study, and to hear different voices on the subject. But all of the managers we spoke to were also librarians by education and we found no major differences regarding notions about the purpose and effects of AD between the three groups. Therefore we refer to all our interviewees as librarians in the article. However as stated above, the denominations following the quotes allows the reader to identify the organizational status of the interviewee. The interviews were interpreted using the analytical framework below.

\section{Analytical framework ${ }^{4}$}

The basic premise for the analysis is that three interrelated variables determine an understanding of the purpose and effects of RA/AD in public libraries. The three variables are (1) cultural Policy and logics of arts advocacy (Jensen, 2003), (2) institutionalized logics of New Public Management, specifically the focus on performance metrics and the desire for increased visibility in the community and (3) issues related to Professional logics of librarians. The relation between issues and notions can be understood as illustrated in the model in Figure 1.

\section{$P$ for Policy: Cultural policy}

Concerning the first point, Policy, we will study how the statements found in the interviews can be understood in the light of the prevailing rationales in cultural policy in general, and library and literature policies in particular. As we will show further on, cultural policy rationales have a close relationship with the library professionals' understanding of how and why their work should be done.

The development of cultural policy in Denmark is usually understood through the concept of rationales (SkotHansen, 1999, 2005, 2006). Cultural policy rests upon the liberal humanist tradition which emphasizes the rights of all people to benefit from (good) culture. The appropriate strategy for this rationale is democratization of culture, and the desired outcome is an educated people. Today several other rationales prevails in cultural policy (SkotHansen, 2005) and new concepts have emerged in the cultural sector, i.e. experience and entertainment which transform the policy and thus the $\mathrm{AD}$ in the direction of more user-oriented library service and a non-judgmental approach to RA (Ross et al., 2006). A similar understanding can be found in the work on arts advocacy by Joli Jensen (2003). Jensen introduces the concept of instrumental logic versus expressive logic and connects it to the concept of aesthetic experiences. According to Jensen instrumental logic is closely connected to a traditional, elitist and excluding approach to art advocacy, with a clear distinction between high culture and low culture. Arts advocacy with focus on an expressive logic, on the other hand, is defined by tolerance and inclusiveness both regarding forms of culture, types of aesthetic experiences and regarding participants.

In Denmark, cultural policy regarding libraries or literature is often being implemented at an institutional level through guidelines published in reports from the Danish Agency for Library and Media. Recent reports on library services (Styrelsen for Bibliotek og Medier, 2008, 2010) reflects the above mentioned movements towards a usercentred approach to RA/AD. The library as institution is viewed as a central player in the development of the society at large, both as a provider of information but also as an institution where media of all kinds are acquired by the library according to quality, comprehensiveness and topicality. ${ }^{5}$ The library is still being characterized, traditionally, as a promoter of knowledge, education and culture, concepts that correspond with the humanist rationale, but today this is combined with consideration of the cultural diversity and equality which characterizes the late modern society.

The current cultural policy and library policy balances between a traditional understanding of culture and literature as means for supporting literacy and education on the one hand and a user-centred approach which emphasizes experience and recognition. As a consequence the concept 
of quality is increasingly based on the users' experience and a more diverse perspective on taste and quality.

\section{$P$ for Public management: Customer orientation and visibility}

Like all other public institutions libraries are subjected to political and administrative demands that go further than rationales of cultural policies. Besides focusing on enlightenment and experience rationales, libraries must tend to visibility, competition and performance metrics in order to be successful today. These demands are in different ways related to the concept of New Public Management (NPM), but can also be viewed as general demands in the late modern society (Buschman, 2003; Jochumsen and Hvenegaard Rasmussen, 2006; Kann-Christensen and Andersen, 2009).

NPM is concerned with improving the efficiency of the public sector through the means of the market, and have been institutionalized both as reforms, discourse and logics in the entire western world (Belfiore, 2004; Hood, 1991; Hood and Peters, 2004). NPM is based on a belief that competition among institutions will improve the efficiency and quality of the services they provide. Consequently public libraries become subject to performance measurement, bench marking, etc. The underlying intent of these efforts is to make production and use of resources in the public sector more controllable, legitimate and transparent (Jarlov and Melander, 2005). As stated above, NPM has influenced the profession in different ways. But also the library as an institution has changed due to the influence of NPM. Today's 'audit culture' has made performance metrics, marketing and organizational development everyday activities in contemporary libraries. In relation to $\mathrm{AD}$, performance indicators, such as circulation numbers have created library services which are orientated towards users' demands.

\section{P for Profession: Professional logics and trends in audience development}

Historically the librarian has been constructed as a professional. According to Skouvig (2008) the traditional librarian was called to teach the population to read - and to read the right books. Skouvig connects this to the concept of 'library spirit'. Librarians with the right spirit will treat all patrons equally and will follow their calling to enlighten and educate the citizen of any given society. The librarian has been analysed and described in several other places. Some researchers have focused on the stereotype (Radford and Radford, 2003) others on the library profession (Dilevkov, 2009; Elbeshausen and Schreiber, 2006). Professional logics in libraries have influence on the notions on RA/AD since this is anchored in professional decisions and direct interaction with users. The concept of professional logics is discussed in detail in Balling and Kann-Christensen (2011).

As stated above we interviewed three groups of professionals, managers, librarians and other academic staff, who all work with RA/AD in different ways and on different levels. The aim of this article is not to identify a coherent professional identity, but even though not all of our interviewees are librarians, they display a homogenous attitude towards users, that is closely connected to what has been described as characteristic for librarians. Similar to the development in cultural policy, librarians' orientation towards their users' needs and preferences has evolved and gradually become more user-oriented in the last 30 years (Ross et al., 2006). This corresponds with the findings of Jochumsen and Hvenegaard Rasmussen (2006) who analysed Danish public library periodicals from 1964 until recent times. They show that among librarians, a certain discourse and attitude towards users has evolved from an unambiguous (elitist) concept of quality to be presented to users towards a wish to get in touch with the public on their terms. The latter attitude became consolidated in Denmark during the 1990s and beyond. Accordingly, by now, no one in the field of public libraries will question that public libraries should reflect their users' preferences and needs. It has become a norm. Johannsen (2009) confirms these conclusions regarding librarians' view on users. Similar conclusions can be found in the work of Jofrid Karner Smidt in her study of literary taste among Norwegian librarians (Karner Smidt, 2002). Karner Smidt concludes that librarians are highly concerned about not educating or sermonizing. Rather, they emphasize the democratic ideal and equality as a central value in their professional work. They give legitimacy and respect to a variety of readers' tastes and preferences and regard all of them as equally important.

\section{Activities related to readers' advisory and audience development}

This article argues that RA/AD take place in the intersection between the above mentioned rationales, logics and demands related to the 3Ps. Before we look into the interviews in the light of the analytic framework we would like to present an overview of the kind of activities the interviewees talk about. Table 1 is thus not a result of a questionnaire, but is a list of activities mentioned specifically in the interviews.

In the interviews the librarians make a general distinction between direct and indirect activities where indirect activities relates to textual promotion and displays and direct promotion relates to events, reading groups, advisory interviews and other activities involving a direct contact between librarian and user. Even though the digital revolution has created new possibilities, it is still the direct interaction with users that concerns the librarians the most. 
Table I. Activities mentioned in interviews.

\begin{tabular}{|c|c|c|c|c|c|c|}
\hline Types of promotional activities/Library & A & B & $\mathrm{C}$ & $\mathrm{D}$ & $\mathrm{E}$ & $\mathrm{F}$ \\
\hline Book cafés & $\mathrm{x}$ & $x$ & $\mathrm{X}$ & $\mathrm{X}$ & $x$ & $\mathrm{X}$ \\
\hline Reading groups & $\mathrm{x}$ & $x$ & $\mathrm{X}$ & $\mathrm{X}$ & $x$ & $\mathrm{X}$ \\
\hline Attractive book displays to create an inspiring physical space & $x$ & $x$ & $\mathrm{X}$ & $\mathrm{X}$ & $x$ & $\mathrm{X}$ \\
\hline Advisory interviews and individual guidance & $\mathrm{x}$ & $x$ & $\mathrm{X}$ & $\mathrm{X}$ & $\mathrm{x}$ & $\mathrm{X}$ \\
\hline Author talks & $\mathrm{x}$ & $\mathrm{x}$ & & $\mathrm{X}$ & $x$ & $\mathrm{X}$ \\
\hline Book talks & $\mathrm{x}$ & $\mathrm{x}$ & $\mathrm{X}$ & $\mathrm{X}$ & & $\mathrm{X}$ \\
\hline Online reading suggestions (the library homepage) & $\mathrm{X}$ & & $\mathrm{X}$ & $\mathrm{X}$ & & $\mathrm{X}$ \\
\hline Litteratursiden (national web portal on literature) & & $x$ & $\mathrm{X}$ & & $x$ & $\mathrm{X}$ \\
\hline Multiple copies of the same book (in stacks) & $\mathrm{x}$ & & & $\mathrm{X}$ & & $\mathrm{X}$ \\
\hline Recommendations in local media & $\mathrm{x}$ & & $\mathrm{X}$ & & $x$ & \\
\hline Participation in large-scale community events & & & $\mathrm{X}$ & $\mathrm{X}$ & $x$ & \\
\hline Special activities for volunteers & $\mathrm{X}$ & & $\mathrm{X}$ & & & \\
\hline Creative writing workshops & $x$ & & $x$ & & & \\
\hline
\end{tabular}

In the following section the interviews are discussed according to three lines of arguments relating to the purpose and effects of RA/AD. Thus we have categorized the statements according to how librarians and managers relate to the possible benefits from $\mathrm{AD}$ and RA activities. It is the identified patterns in the interviews which structure the following analysis.

\section{What reading does (What's in it for the users?)}

In the analysis of the arguments put forward by librarians regarding the purpose and effects of RA/AD we can identify three lines of arguments. These arguments address the how, the what, and the why of RA/AD. The 'how' encompasses the setting and the type of activity related to RA/ AD. The 'what' describes the content of activities (i.e. types of reading matters). Finally, the 'why' investigates the process of reading and its benefits.

\section{Readers' advisory and audience development: How to do it}

Addressing the purposes and effect of RA/AD, participating librarians point to the importance of creating experiences for users. The following statement reaffirms the experiential value of $\mathrm{RA} / \mathrm{AD}$ activities:

The most important thing for me is not to educate users about literature. The most important thing is to make sure that they have a pleasant and memorable experience and to make them feel that an event is focused on them (C3).

The focus on experience is found in many different activities but becomes very explicit in connection with such RA/ $\mathrm{AD}$ events as book cafés, whereby thematic book presentations are accompanied by food, music, wine, or other features. As a result, a holistic experience, which appeals to several senses, is created. In all six libraries, these book cafés play a major role in RA/AD activities.

We have taken the concept of book talking onto the next level.
We collected some feedback on how to present books in an
engaging way, so that people are not bored to death. And so
we have added music to play along with the theme of the book
talk, just to spice it up. We also serve something - a cup of
coffee, a piece of cake, a glass of wine, or a piece of cheese.
Overtime, the concept has really evolved. It has acquired
more depth and more substance. (D2)

Also the physical display and the library space should support the experience. This is a remark by one librarian with regard to promoting literature about India:

We actually used incense [...] and wow - it really worked! But the sound ... we are not too good at it, but we keep playing around with this idea. We are trying to appeal to all senses. (F1)

Both the library space and the actual activities should be inspiring:

It should whet the readers' appetite. (D2)

The actual experience should not be seen as extraneous and tangential; it is not just fast food without nutritious value. Rather, it is to be seen as having merit in and of itself, irrespective of the educational and aesthetical content. It is to be seen as something extraordinary that engages both intellectual and emotional faculties of the user and leaves him/her transformed (Balling, 2009; Dewey, 2005; Grøn, 2010; Jensen, 2003; Shusterman, 1999). The concept of RA/AD as experience thus stands not to promote a certain kind of literature but to enable a variety of experiences.

This notion is also connected with accepting users' tastes. All interviews included statements about the 
importance of accepting and giving legitimacy to readers' choices:

As we all know, people want to participate; they want to feel free to express their opinions. They also want to engage with other people who respect their opinions. They don't want a stern librarian slap them on the wrist and scold them for not understanding Dostoevsky. (C2)

The acceptance of users' tastes is inseparable from a new librarian identity, whereby the librarian and the user are viewed as equal partners and collaborators (Balling et al., 2008; Johannsen, 2009). If RA/AD is viewed as collaboration, the focus shifts from the reading matter in question onto the experience, the dialogue, and the social event, which give users satisfaction and enjoyment:

They should feel welcomed, accepted, and understood and have a personal experience. (F2)

They should also feel very welcomed. Kindly treated, respected and understood. [They should feel] that people here in the library engage in listening to them and talking with them. (B1)

$\mathrm{RA} / \mathrm{AD}$ is here not seen as a means to promote literature, but as a means to focus on users and engage them in a conversation. 'You should meet people at their own level' as one of the librarians (C3) expresses it. This approach to $\mathrm{RA} / \mathrm{AD}$ encourages users to engage in discussing books and reading. But also as a means to make the library a nice place to be.

\section{Literature: What should be promoted?}

Although RA/AD is primary focused on the user experience, the types of books chosen for promotion also deserve attention. As follows from the interviews, most librarians support the promotion of diverse reading matters:

The idea of RA/AD is to give people experiences they didn't expect, and to help people realize that their library is one of the best places to seek and discover new things. (A2)

The purpose is to expand readers' horizons ... I don't necessarily refer to literary fiction; I mostly talk about the diversity of genres available. (B1)

We should encourage people to read something other than what they are usually exposed to, i.e. ubiquitous bestsellers. We should shift readers' focus away from bestsellers. Well, we make bestsellers available, but we don't have to actively promote them. They promote themselves. (D1)

Although these librarians express respect to users' choices and attribute value to the experience of reading, their desire to elevate readers' tastes by promoting what they consider to be 'good' or 'quality' literature is very tangible. To some point the statements represent the 'reading ladder' approach (Duelund, 1995), which ranks reading genres hierarchically into high and low and draws a clear distinction between 'good' and 'bad' literature. The same approach also presupposes introducing people to reading materials that are higher up the reading ladder than their usual reading choices. Using Kawashima's different types of $\mathrm{AD}$, it becomes evident that the interviewees think in the direction of the AD that targets existing audiences and focuses on taste cultivation.

Thus the strategy here is not to target new audiences but to educate the existing audiences. The librarians do not want to stop people from reading their preferred type of literature, but they seek to introduce readers to titles outside the mainstream literature. Other statements pinpoint some of the arguments from a well-known discussion on literature quality and the role of the librarian. Should the librarians take a stand when it comes to buying and promoting 'bad' literature?

We have to have the courage to take a stand, to say to a user: 'It's not bad what you like to read. We would just like to show you something else'. We have also Margit Sandemo, ${ }^{6}$ to my horror. This is really bad. This is real trash. But people love it. (B1)

When asked about quality some librarians express frustration in relation to selection and promotion. Due to the national search system Bibliotek.dk where library users can order titles from all Danish libraries, they feel obliged to acquire titles that they would not have acquired earlier.

We feel the pressure to respond to users' demand. We can no longer rely on selection criteria that we used in the past. Bibliotek.dk means that we have to buy books we wouldn't have bought 10 years ago. But in relation to displays and when we talk to readers we can be much more selective what we present and how. (E1)

The quality discussion which is approached here is present in the interviews, but very subtle. The librarians cannot reject certain queries, but they can decide which books to put on displays and select for book talks.

We have two tables in the hall holding the books that have just been returned. We know that these books will be borrowed again right away. What sits on these tables means a lot to me. There should not be a pile of Sandemo's The Legend of the Ice People. I simply remove these books. (C1)

Even though the librarians demonstrate a certain degree of acceptance of users' reading preferences, this acceptance seems to have limits. The manifold cultural orientation as described above is clearly the ideal, but the reading ladder approach still influences some librarian's notions on RA/ AD. The last quote illustrates how the librarians' struggle 
for maintaining a 'good quality' selection takes place unseen. Librarians balance between a wish to support the reading experience on the one hand and a struggle to widen users' taste and choices in literature on the other hand. Statements regarding specific types of literature as bad are most explicit among older librarians; the same librarians who speak passionately about a more dialogue-oriented relation to users which characterizes the work today compared with previously.

The primary focus on users' experiences downplays the discussion on quality. Instead, acknowledgement and diversity is viewed as important points of orientation when it comes to the purpose of RA/AD. Actually the librarian quoted above does the opposite of what she says. In censoring readers' choices she clearly does not 'put the readers in the driver's seat' as Ross et al. (2006: 210) describes the North American approach to RA today. However, this censoring act, as we will see in the following paragraph, seems to derive from the librarian's own passionate relation to literature and her desire to pass good reading experiences on to users. The question about experience vs. quality is not necessarily a question of opposites; nevertheless it contains a challenge for some librarians.

\section{Reading: Why do it at all?}

What is the purpose of RA/AD? What should people gain from reading? This last line of arguments regard the general benefits of reading experience as put forward by several librarians:

[Literature] is the most important thing in the world. [...] It makes a difference in people's lives. (E1)

I think it enriches people's lives. We make life more fun. (On effects of RA/AD) (B1)

We give them a richer life. (C3)

You become more empathic. And maybe more tolerant I think that is very good virtues. (On reading) E2

The statements point to a general consensus that reading is good. This is not questioned. Librarians help users become educated and informed citizens. But as the above mentioned statements show there are voices among the librarians for whom not all reading is good reading.

To sum up, RA/AD can be seen as activities that ranges between a humanist rationale where reading of good literature creates good people and an experience rationale where the most important raison d'être for RA/AD activities is that people should feel acknowledged and have a good experience. As we will return to later, the statements regarding the value of reading and the book choices can also be understood in relation to librarians' own identity as readers.

\section{Legitimacy (What's in it for the library?)}

Analysing the interviews, a group of statements were identified which pointed towards the benefits for the library itself. The librarians are concerned about the role, the legitimacy and the visibility of the library in the community. This paragraph discusses the statements made regarding the libraries' legitimacy and understanding of the users. The legitimacy of the library today is closely (but not solely) connected to NPM (P for Public Management), as we will show in the following. The statements in this category follow two lines of arguments (notions).

The first line of arguments relate to statements about what a library is, what users, librarians and politicians expect from the library. These statements relate to an implicit consensus of what the library is, and what role AD plays accordingly. The second line of arguments regards the demands the library is subjected to regarding measurement of the library's activities. This relates explicitly to the expectations and wishes of the libraries' principals in the municipality, but it also relates to the professional satisfaction, the feeling of personal legitimacy of the librarians. This line considers the need for the library to be visible in the local society.

\section{RA/AD as core activities}

$\mathrm{RA} / \mathrm{AD}$ are characterized as core activities by several of those interviewed. When asked why they engage in these activities, the interviewees put forward these statements:

The easiest and the most boring answer is that this is something we have to do. It's the core activity. Whooo. (B3)

It's a core activity, that's why it's important. (F1)

Fiction is not the type that has the highest lending rates. But it is what people think is our core activity, to borrow novels. (B1)

The above statements point towards a notion on RA/AD as an essential activity. There is no explicit regulative basis in the Act Regarding Library Services (2000), though, that libraries should promote literature, only that they should secure access to literature, but the implicit understanding of this necessity in the statements above is supported by many policy documents. The latest example is the report on public libraries in the knowledge society (Styrelsen for Bibliotek og Medier, 2010). In several places this report equals 'traditional core activities' with RA/AD (see e.g. pp. 7-8 and pp. 51-53). This points towards a notion on $\mathrm{RA} / \mathrm{AD}$ as something that rests deeply in the selfunderstanding of the institution. This is present on both the political and the practical level.

What is interesting is the way the above statements are put forward. The first interviewee somehow feels she has 
to distance herself from the concept of core activity. The use of 'whooo' and the characteristic 'boring' indicates that $\mathrm{RA} / \mathrm{AD}$ has a higher value that just some municipal boring core activity. This is linked to a notion about the legitimacy of RA/AD in libraries that goes beyond the political. It has an exciting value in itself. The other two statements connect the legitimacy of RA/AD to the users' expectations. RA/AD concerns what a library is and what it should do. If users think that RA/AD is the core activity, then it (automatically) becomes the core activity. This focus on the users is present in several places in the empirical material. And as we will show in the following, the users are present everywhere in the notions on the legitimacy of RA/AD in libraries.

\section{Quantity as quality}

In the following we discuss the interviewees' statements regarding quantitative measurements such as performance metrics. One statement shows that the link between funding and lending rates is experienced as very close:

We had a specific objective in our agreement with the municipality with regard to circulation statistics ... Our selection and acquisition policy reflected this. We bought multiple copies to shorten waiting lists and reduce the waiting time. We consciously responded to users' demands [for popular titles] so they could take out as many as possible. This approach guarantees us continued funding. This is what we are evaluated on. Very much so; circulation stats and the number of visitors. (A1)

Increased circulation is emphasized as an effect of good $\mathrm{RA} / \mathrm{AD}$. The statement shows how certain efforts can increase lending rates. This very explicit focus on performance measurement can be viewed as a result of the strong NPM influence in the libraries. In the statement above it is directly linked to the library's funding. The library is not funded according to measurements of how good it is at recognizing what role it can play in a citizen's life at a given time, but solely on a quantitative measure (Kann-Christensen and Andersen, 2009). But librarians also display a more implicit NPM-stance. An example of this is the answers to the question on best and worst experiences with $\mathrm{RA} / \mathrm{AD}$ activities like literary events:

There have to be people attending. It's best if there are lots of people coming. I might as well be honest and say so. It's no use to put an event together if only 7 people attend. (B2)

If I dig deep [into myself] the criterion for success is that there must be people attending. The result must be able to measure up against the efforts. I don't want to put together something if only three people attend. (C2)

The worst is if nobody shows up. That ruins my mood. (A3)
Even though the number of people varies in the above statements, the overall criterion for success regarding literary events in the library is the number of people attending. It is noticeable that two of the three librarians incorporate a distance towards their own statement. It is obviously not comme il faut to display this quantitative perspective on events. Nevertheless, it seems that the number of people attending the literary events and the number of volunteers are very present in the interviews. This quantitative emphasis points towards a strong customer orientation or what Kann-Christensen and Andersen (2009) call a 'customer satisfaction view'. The absence of users means that something has been done wrong. This can be either a wrong concept or lack of marketing. Nowhere in the interviews can it be identified that it is the customers that are wrong (in not attending). The number of attendees/volunteers becomes synonymous with the quality of the concept or event. The arguments made for these viewpoints are twofold.

The first argument regards the overarching challenge for the libraries. The collection plays a smaller and smaller role in the core activities of the libraries and promotional activities plays a more important role. Because connections (as opposed to collections) have become the core activity, the library must be able to deliver when it comes to events if they want to sustain legitimacy.

The second argument regards the visibility of the library. Events market the library, and the more people who attend the more visible the library is to other potential customers. RA/AD becomes a means to improve the library's visibility. Actually the only thing that can make an otherwise poorly visited event a success is if the media report from the event:

When we did the speed-lit event, which is a variety of speed dating, 22 people attended. [...] that's not a lot, but when you think about that the news reported live from the event $[\ldots]$ and all the major newspapers wrote about speed dating at our library, that made up for it; because we had a lot of publicity. (C2)

In our opinion events brands the library. It's what gets us in the newspaper. (E2)

We have cooperated with local breweries. They came down and served beer [at a book cafe]. It is important to let the community know that we are a library with more than books on shelves. So this partnership can bring something more ... We primarily do it for the citizens but a side effect has been that it has been really good [for branding the library]. (D2)

The events brand the library as a place where something is happening which is important both in relation to politicians and to present and potential users. This reflects an assumption that if the library is visible, it will attract more users and thus gain more legitimacy. A variant of this line of thinking is put forward by librarians that link the quantity of users to a concern for how taxpayers' money is 
spent. RA/AD activities must appeal to a broad audience; many citizens should benefit from the library.

In other words: what benefits does $\mathrm{RA} / \mathrm{AD}$ have for the overall legitimacy of the library? The answer to this question is closely related to a certain notion of users as customers that needs to be satisfied. Users become a means to legitimize the library to politicians who will evaluate the library in economic terms (performance metrics). In other words, it becomes imperative for libraries to be able to document that they have satisfied users and that they strive to make themselves visible to all potential customers. Thus quantitative performance measurement plays a role when it comes to understanding the library professional notions on the purpose and effects of RA/AD.

Thus when it comes to benefits for the library, the notions on $\mathrm{AD}$ concerns Kawashima's third type of $\mathrm{AD}$, extended marketing. But the 'market' also includes politicians and potential partners.

\section{The dedicated librarian (What's in it for me?)}

Analysing the interviews with a focus on the benefits of the librarians themselves, two lines of arguments come forth. The first emphasizes the librarians' own identity as readers and their passionate relation to books and reading. The second line focuses on their identity and competences as library professionals. At first, these lines seems opposing, but a closer look reveals that the librarians in their daily work try to balance these two identities and that both identities are driven by dedication. In many cases the librarian as a fellow reader and the librarian as a professional combine nicely, but the double identity also holds some challenges.

The first line of arguments shows how close the role as librarian and the person's own literary preferences and pleasure for reading are connected:

I have chosen to take my own top 5 or top 3. My favourite books, and then it's just so nice to see people almost fight over them (on book talks). (A2)

I think is has to do with passion ... You have read a good book and you would like other people to have the same experience. (F2)

These statements are examples of how the librarian's own taste determines the books $\mathrm{s} / \mathrm{he}$ promotes. This notion of $\mathrm{RA} / \mathrm{AD}$ can be found in most of the interviews. The librarians justify this use of personal preferences with the argument that passion and dedication towards books and reading creates a passionate communication:

You can provide much better advice if you recommend the books you are passionate about. That doesn't mean that we can't recommend other reading materials. But advisory is the best if you are passionate about it. (E1)
It is totally natural that the librarian takes her point of departure in her own taste. (F1)

Users think it's very exciting to hear what we have to say. Not only do we provide them with the summary of the book and its reviews. We also bring in some personal touch. We have read this book, and we would like to tell readers that it is a great book. We remove our professional mask and let them know that we are not only librarians but also readers, just like them, and as readers, we can share our personal experience with the book. (D2)

The last statement shows very distinctively how librarians use themselves as the point of departure in RA/AD activities. Librarians recommend books they love, and promote them in ways they find exiting themselves. According to the librarians this strategy generates the best impact. But it also increases their job satisfaction since the personal taste and interest becomes the core content in their work with $\mathrm{RA} / \mathrm{AD}$. Interestingly the librarian seems to be glad to remove her professional 'mask'. This leads to the second line of argument which concerns professional competencies. When asked about what has changed during the last decades, one librarian answers:

At library school we were introduced to the reference interview that was prevailing at the time. At that time we were professional experts that were supposed to ask certain questions in a certain order. But today we give a personal service. Now I am allowed to be [name] when I interact with a user. Now I can have an opinion about a book, or if they ask me if I have read a specific book I am allowed to say no, or to say yes but that I didn't find it so good. We are allowed to have a personal perspective today. That was not comme il faut at that time. [...] We were professional experts. (D2)

It is tempting to conclude that librarians today see themselves as readers more than professionals. But that is not the case. Rather the professional expert role has changed due to changes in library use. First and foremost the profession and thus the needed skills have changed from having a focus on the collection to having a focus on relations with users. Today a good librarian is someone who is able to communicate and to call people's attention to the many services and offers the library holds:

It's no secret that we would like to open people's eyes to the possibilities at the library; that we are a serious place where you can go if you need information or experiences; that we are an alternative to many other things you can do. (D1)

In relation to $\mathrm{RA}$ as well as $\mathrm{AD}$, professional pride is related to situations where they succeed in bringing book and user together or when they open users' eyes to other types of literature than their preferred:

When I'm at the reference desk, it's the best when a user comes and says to me: 'Oh great that you are here, the book 
you recommended last time was so good'. I like that because it means I was spot on. I had found the right book. (F2)

The above mentioned personal strategy in RA/AD has advantages but it also has limits since it primarily tends to target users who have similar preferences as the librarians. When confronted with users of another gender and age several librarians experience difficulties:

It is easy for me to find books for someone like myself, but it is difficult with a young man at 21 who says no to all my suggestions and can't articulate what he wants. (F2)

Especially with young students who don't want books with more than 100 pages and you ask them all sorts of questions: do you have a hobby? What do you find interesting? After 20 suggestions you become very tired when they still aren't interested. That is a challenge. And you think: what should I do next? Then I show them Litteratursiden. ${ }^{7}$ (D2)

The role as both fellow reader and as professional expert is driven by dedication and love for literature. The change in the relation between librarians and users as expressed by one of the interviewees has created more committed and enthusiastic librarians. They love their work and they enjoy the more personal and equal relation to users, though the statements above also suggest that librarians do not enjoy the encounters with users who cannot articulate what they like.

$\mathrm{RA} / \mathrm{AD}$ driven by passion and shared literary preferences have limitations. These limitations affect users whose tastes, preferences and even abilities to express these preferences differ from the librarians. We will return to this challenge in the discussion below.

\section{Concluding discussion}

The study of notions about RA/AD among librarians at Danish libraries shows us several points of interest. Danish librarians perform very user-oriented RA/AD that balances experience and enlightenment. Users should have a good experience, should feel welcomed to the library regardless of their literary taste. But reading should also transform library users into better, more empathic and educated people. RA/AD is still seen as a core activity and despite the digital revolution, the direct interaction with users is very much in focus. At the same time the librarians are aware that they must meet the demand for visibility and customer satisfaction related to the demands of new public management.

User orientation and focus on experiences have created a situation where notions of passion, commitment and enthusiasm pervade the interviews. Librarians put themselves in the centre of the activities and they experience feelings of success when they do it. It actually seems to work.

As mentioned above, the problem is that this form of $\mathrm{RA} / \mathrm{AD}$ has limitations when it comes to content and target

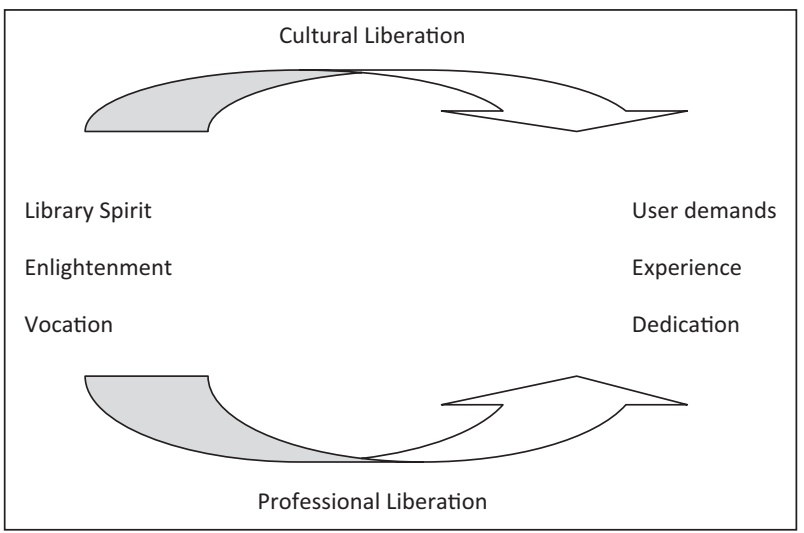

Figure 2. The context of readers' advisory and audience development.

group of the activities. If personal commitment is necessary to be a good librarian, how do you advise people with preferences different from your own? RA/AD founded in dedication and experience tends to target users who look and thinks like the librarians. In Figure 2 we have created a model that shows the development of the context of RA/ AD from the 1960s until today which explains why librarians are left with dedication as the driving force in their work.

The model uses the German sociologist Thomas Ziehe's (1983) concept of cultural liberation. This concept refers to the processes in society in the 1960s and 1970s which dissolve traditional values and constraints of tradition. Before this liberation, the identity of librarians and the content of library activities were stable and clearly defined. The medium was the book, the concept of quality was linked to the humanist liberal tradition and the purpose of the library was enlightenment (Hvenegaard Rasmussen and Jochumsen, 2007). Furthermore, librarians were experts who had the authority to decide which books were of good quality and which were not. The library as institution was tied to a library spirit where the driving force was to educate the people and create an enlightened population. The essential criteria for RA were founded in societal and institutional norms on quality that worked as guiding principles for the librarians.

The cultural liberation in the 1960s and 1970s, as well as the customer orientation related to the societal development in the 1980s and 1990s creates liberation, both of the cultural norms and quality criteria and also of the librarian profession that faces liberation in relation to norms and values regarding literary genres and to behaviour towards users. Hvenegaard Rasmussen and Jochumsen (2003: 85 ff.) discuss this issue as a question of a changing librarian's doxa. However, our study shows that the liberation also has left librarians without a common goal and has forced them to seek the purpose and meaning of their work on a more individual basis. 
The model shows the continuum that characterizes the field of RA/AD today and aims to explain the challenges that librarians face in their daily work. It also shows that notions among the interviewees can be found in the same continuum between an old ideal of enlightenment where there still is a wish to present users with a variety of literature and a new ideal solely related to experiences and acknowledgement of the user.

The commitment and passion that characterizes the librarians' statements is thus not based in a humanist (enlightenment) or even sociological (empowerment) rationale. Rather it is based partly upon a desire to satisfy customers and partly upon a desire to satisfy the librarians themselves. In that way the experience rationale that pervades libraries today can be seen as an obstacle when it comes to promoting reading to all users. On the one hand you have to be passionate and committed to be a good librarian. On the other hand the commitment founded in the personal preferences means that you cannot reach everybody.

\section{Funding}

This research received no specific grant from any funding agency in the public, commercial, or not-for-profit sectors.

\section{Notes}

1. The author Kann-Christensen is identical with KannRasmussen.

2. The term 'formidling', which derives from the German term 'Vermittlung', means communication, mediation and education and can describe various activities related to the availability, dissemination and display of reading materials, and direct interactions with audiences.

3. The reason for the time elapsed between the first interviews and the publication of this article is that we developed an analytical framework (Balling and Kann-Christensen, 2011) on the basis of the first round of interviews, and then undertook this study to gather additional data.

4. The following paragraphs build upon Balling and KannChristensen (2011)

5. According to the Danish Act Regarding Library Services.

6. Margit Sandemo is a Swedish-Norwegian author of a bestselling historical fantasy series which covers no less than 47 books.

7. Litteratursiden (the literary page) is a website developed and maintained by a network of Danish public libraries. It contains reviews of books, portraits of authors, virtual reading groups as well as options for users to review and comment.

\section{References}

Act Regarding Library Services (2000) Available at: http:// www.bs.dk/publikationer/english/act/index.htm (accessed 1 November 2012).

Audunson R (2005) The public library as a meeting-place in a multicultural and digital context: The necessity of lowintensive meeting-places. Journal of Documentation 61(3): 429-441.
Bak L et al. (2012) Danskernes Kulturvaner. Copenhagen: Kulturministeriet.

Balling G (2009) Littercer cestetisk oplevelse: Loesning laeseoplevelser og loeseundersøgelser: En diskussion af teoretiske og metodiske tilgange. PhD Dissertation, Royal School of Library and Information Science, Copenhagen, Denmark.

Balling G and Kann-Christensen N (2011) Literature promotion in public libraries: Between Policy, Profession and Public Management. Nordic Journal of Cultural Policy 2011(1/2): $100-119$.

Balling G, Henrichsen LA and Skouvig L (2008) Digital reading groups: Renewing the librarian image. New Library World 109(1/2): 56-64.

Belfiore E (2004) Auditing culture. International Journal of Cultural Policy 10(2): 183-202.

Buschman JE (2003) Dismantling the Public Sphere: Situating and Sustaining Librarianship in the Age of the New Public Philosophy. Westport, CT: Libraries Unlimited.

Dewey J (2005) Art as experience. New York: Perigee.

Dilevkov J (2009) The Politics of Professionalism: A RetroProgressive Proposal for Librarianship. Duluth, MN: Library Juice Press.

Duelund P (1995) Den danske kulturmodel. En idepolitisk redegørelse. Copenhagen: Klim.

Elbeshausen H and Schreiber T (eds) (2006) Bibliotekarerne: En profession $i$ et felt af viden, kommunikation og teknologi. Copenhagen: Samfundslitteratur.

Grøn R (2010) Oplevelsens rammer. Former og rationaler $i$ den aktuelle formidling af skønlitteratur for voksne på danske folkebiblioteker. PhD Dissertation, Royal School of Library and Information Science, Copenhagen, Denmark.

Hood C and Peters G (2004) The middle aging of new public management: Into the age of paradox? Journal of Public Administration Research and Theory 14(3): 267-282.

Hood C (1991) A public management for all seasons. Public Administration 69(1): 3-19.

Hvenegaard Rasmussen C and Jochumsen H (2003) Strategies for the public library in the 21 st century. International Journal of Cultural Policy 9(1): 83-93.

Hvenegaard Rasmussen C and Jochumsen H (2007) Problems and possibilities: the public library in the borderline between modernity and late modernity. Library Quarterly 77(1): 45-60.

Jarlov S and Melander P (2005) Statens økonomistyringsdiskurs: Forklædte managementreformer, velafrettet ledelsesretorik og indkapslet arbejdspraksis. In: Busch T, Johnsen E, Klausen KK, et al. (eds) Modernisering av offentlig sektor. Oslo: Universitetsforlaget, pp. 107-128.

Jensen J (2003) Expressive logic: A new premise in arts advocacy. Journal of Arts Management, Law and Society 33(1): 65-80.

Jochumsen H and Hvenegaard Rasmussen C (2006) Folkebiblioteket under forandring: Modernitet, felt og diskurs. Copenhagen: Danmarks Biblioteksforenings Forlag.

Johannsen CG (2009) Folkebibliotekernes brugerbilleder: Fire forestillinger om brugeren. Dansk Biblioteksforskning 5(1): $5-16$.

Kann-Christensen N and Andersen J (2009) Developing the library: Between efficiency, accountability and forms of recognition. Journal of Documentation 65(2): 208-222. 
Karner Smidt J (2002) Mellom elite og publikum. Littercer smak og litteraturformidling blant bibliotekarer i norske folkbibliotek. Oslo: Unipub Forlag.

Kawashima N (2006) Audience development and social inclusion in Britain. International Journal of Cultural Policy 12(1): $55-72$.

Kristiansson M (2007) Strategic reflexive conversation: A new theoretical-practice field within LIS. Information Research 12(4). Available at: http://informationr.net/ir/12-4/colis18. html (accessed 1 November 2012).

Radford GP and Radford ML (2003) Librarians and party girls: Cultural studies and the meaning of the librarian. Library Quarterly 73(1): 54-69.

Ross CS et al. (eds) (2006) Reading Matters: What the Research Reveals about Reading, Libraries and Community. Westport, CT. Libraries Unlimited

Shearer KD and Burgin R (eds) (2001) The Readers' Advisor's Companion. Englewood, CO: Libraries Unlimited.

Shusterman R (1999) The end of aesthetic experience. Journal of Aesthetics and Art Criticism 55: 29-41.

Skot-Hansen D (1999) Kultur til tiden: Strategier i den lokale kulturpolitik. Nordisk Kulturpolitisk Tidsskrift 1(1): $7-27$.

Skot-Hansen D (2005) Why urban cultural policies? In: Robinson $\mathrm{J}$ (ed.) EUROCULT21 Integrated Report. Helsinki: EUROCULT21, pp. 31-40. Available at: http://www. eukn.org/E_library/Economy_Knowledge_Employment/ Urban_Economy/Specific_Sectors/Tourism_Recreation Culture/EUROCULT21_Integrated_Report (accessed $\overline{7}$ April 2014).

Skot-Hansen D (2006) Biblioteket i kulturpolitikken: Mellem instrumentel og ekspressiv logik. In: Emerek L, Hvenegaard Rasmussen C and Skot-Hansen D (eds) Folkebiblioteket som forvandlingsrum. Copenhagen: Danmarks Biblioteksforening \& Danmarks Biblioteksskole, pp. 25-40.
Skouvig L (2008) How to observe the librarian. Library History 24(4): 299-306.

Styrelsen for Bibliotek og Medier (Danish Agency for Library and Media (2008) Fremtidens biblioteksbetjening af børn. Copenhagen: Styrelsen for Bibliotek og Medier.

Styrelsen for Bibliotek og Medier (Danish Agency for Library and Media) (2010) Summary from the Committee on Public Libraries in the Knowledge Society. Available at: http://www.kulturstyrelsen.dk/fileadmin/publikationer/ publikationer_engelske/Reports/The_public_libraries_in the_knowledge_society._Summary.pdf (accessed 21 May 2013).

Thorhauge J (2010) The public libraries in the knowledge society. Scandinavian Public Library Quarterly 43(2): 4-7.

Van Riel R and Fowler O (1996) Opening the Book: Finding a Good Read. West Yorkshire: Opening the Book.

Ziehe T (1983) Ny ungdom og uscedvanlige lcereprocesser: Kulturel friscettelse og subjektivitet. Copenhagen: Politisk Revy.

\section{Author biographies}

Nanna Kann-Rasmussen holds a PhD in public library development. She is Associate Professor at the Centre for Cultural Policy Studies, Royal School of Library and Information Science, University of Copenhagen where she teaches courses on cultural policy and organizational theory. Among her research interests are cultural policy, institutional theory and organization studies.

Gitte Balling holds a $\mathrm{PhD}$ in literary aesthetic experiences. She is Assistant Professor at the Centre for Cultural Policy Studies, Royal School of Library and Information Science, University of Copenhagen where she teaches courses on cultural communication and media culture. Among her research interests are cultural communication, literature sociology and cultural policy. 